mastery of knowledge, skills, skills and development of mental abilities. It is also noted that the concept of research is ensured by the unity of methodological, theoretical and methodological aspects. The importance of using problem-oriented situations in stimulating the cognitive activity of cadets is emphasized, that leads to the formation of a stable desire to learn a foreign language, to improve their foreign language communication skills. The success of the intellectual development of cadets of higher military educational institutions is achieved mainly in the classroom, when the teacher organizes cognitive systematic activity of cadets. The article emphasizes that the essence of problem-oriented occupation can be covered by one phrase - creative mastering of knowledge, when the busy cadet goes through all the links of scientific creativity: problem statement and search for a solution - at the stage of knowledge introduction; the expression of the solution and the realization of the product are at the stage of knowledge reproduction. The article emphasizes the effectiveness of the application of the selected pedagogical technology, highlights the methodical methods of creating problem situations, methodical means of organizing a problem-seeking approach, which in general contributes to solve the problems and goals of modern English language vocational communication.

Key words: problem-oriented approach, problem learning, problem situations, creativity, problem tasks, complexity, difficulty, outlook, mental interaction, teaching method.

UDC 37.013.83

DOI https://doi.org/10.31392/NPU-nc.series5.2020.72-1.15

Berestok O. V., Kurinnyj O. V., Shcherbyna Y. M.

\title{
APPLICATION OF INFORMATION COMMUNICATION TECHNOLOGIES AS MEANS OF KNOWLEDGE FORMATION IN THE FOREIGN LANGUAGE TEACHING PROCESS IN HIGHER EDUCATIONAL INSTITUTIONS
}

The article deals with the opportunities provided by information communication technologies (ICT) application in the foreign language teaching process. The ICT- based educational tasks are identified. Different types of activity that facilitate the effective mastering of various aspects of the language studied are described. The advantages of multimedia tools implementation in the educational process of higher education are presented. Several options of multimedia courses used to organize the study of theoretical material are presented. Moodle, as a multi-functionality system, implemented in foreign language classrooms to promote students' learning, is shown. The importance of the use of ICT at the lessons targeted to diversify the learning process and present the training material more visual and accessible for students is highlighted. Integration of the information resources of the Internet into the educational process to solve a number of didactic tasks more effectively is pointed out. Information communication technologies as the mode of education used to support, enhance, and optimize the delivery of information are described. The role and the perspective of teachers who implement ICT at the lessons, highlighting them as crucial players in the educational process, are focused on. The methodological and didactic assumptions that allow us to identify several areas of study are analyzed. On-line activity as a learning tool targeted not only to facilitate interaction and personal contact among people but also develop learning skills during classes in the form of a complementary activity is identified. The key means for innovation in the form of the factors involved for the effective use of ICT is examined. The importance of innovation as the impact of ICT on increasing the quality of education is underlined.

Key words: information communication technologies, multimedia courses, educational process, training material, methodological assistance, learning skills, practical result, intercultural communication.

\section{(статтю подано мовою оригіналу)}

"Technology is just a tool. In terms of getting the kids working together and motivating them, the teacher is the most important"

Currently, when the need for knowledge of foreign languages is recognized as a demand of modern society, contemporary communication-oriented education trains students to use a foreign language in real life for cultural, professional and personal communication with representatives of other nationalities and social groups.

In the contemporary circumstances to study foreign language culture and develop communication skills in English classes more successfully we should implement an effective pedagogical tool, such as ICT training. Teachers note that ICT application helps to accelerate the learning process, increase students' interest in the subject, improve the level of comprehension skills, allow to individualize the educational activity and make it possible to avoid the subjectivity of assessment. Using ICT at foreign language lessons makes it possible to diversify and increase students' interest in foreign language learning, as well as promote success in further activity connected with foreign language application.

The purpose of the article is to study an urgent necessity for ICT-based education aimed to rationalize intellectual activity globally by implementing new information communication technologies and increase the efficiency and quality of highly-qualified specialists training with a new type of thinking that meets the requirements of postindustrial society. 
Nowadays, a new phase of computerization in various scientific disciplines, including foreign languages teaching, caused by the development of multimedia technologies, is being introduced into education. In the interaction they use graphs, animation, photos, video, sound, text to create an integrated information environment where the user can find qualitatively new opportunities that are implemented as a significant means of students' educational activities.

Modern information communication technologies (ICT) provide a whole range of tools for foreign languages teaching, namely: multimedia training programs ("Professor Higgins", “Oxford platinum”, "English platinum”,) and dictionaries (http://spravki.net/), a huge variety of Internet resources, such as educational and authentic materials in foreign languages, electronic versions of foreign newspapers and magazines (http://www.onlinenewspapers.com/), publications (http://www.washtimes.com/), etc. Currently, there are many multimedia learning tools available, such as "Tell me more", "English: the path to excellence", interactive courses, etc. [1, p. 30].

Multimedia tools in the educational process of higher education can be presented in electronic textbooks, selfprepared teaching material, presentation of information using the PowerPoint program, video method, e-mail, roleplaying game, electronic interactive whiteboard, etc. [2, p. 126].

It is worth mentioning that with the help of the implementation of computer programs at the lesson, information provided to students is colorfully designed, using animation effects, in the form of text, diagrams, graphics, drawings. All this, according to modern didactics, allows us to explain the training material more clearly than we do it only verbally. It is also very important that at such lessons a student can work in an individual mode, moving forward in comprehending new material at his own pace, returning to the incomprehensible, if necessary, or looking ahead [3, p. 19].

The following types of multimedia courses can be used to organize the study of the theoretical material, namely:

- video lectures. The lecture of the teacher is recorded on a videotape. The undoubted advantage of this method of presentation is the ability to listen to the lecture at any time, referring to the most difficult parts whenever you want;

- multimedia lecture. Interactive computer training programs can be implemented in the process of independent work on the lecture material. Learning effect in multimedia programs is achieved not only with the help of content and friendly interface, but also by using, for instance, testing programs that allow the student to assess the degree of mastering of the theoretical educational material;

- traditional educational publications: electronic lectures, reference notes, methodological assistance to study theoretical material, etc. [4, p. 87].

Nowadays, one of the most popular resources that is widely used in institutions of higher education is the Moodle system.

This system can be used as a supplement of the foreign language teaching, as a means to upload and share documents, to assign students' homework and encourage them to download learning material being outside the class, providing the opportunity to practice English learning skills sitting at home. Besides, it makes course administration easier and helps to reduce the cost and time of delivering instruction. Thus, there are some problems when using Moodle in English language teaching [5].

One of the disadvantages of online teaching is low engagement and higher dropout rates in comparison with offline traditional learning methods. Moodle teachers also face the problem of low student interaction within the course.

To evaluate the interaction in Moodle course, it is essential to measure how long the students are online. The course gives a good opportunity to use the dedication plugin to check 3 different reports, such as:

Dedication of individual student: detailed sessions for a student with start date and time, terms and IP address.

Dedication time for each student in the course: calculates total dedication time, mean dedication time and connections per day for each student in the course.

Dedication time of a group of students: the same but only for chosen group members [6].

One of the options for achieving the goal is the use of information and communication technologies, where electronic means are increasingly being used as sources of information. Each lesson of a foreign language should be aimed at a practical result, at achievement of communicative competence, i.e., a certain level of linguistic, regional geographic knowledge, communicative skills and speech skills that contribute to foreign language communication. The use of ICT at the lessons promotes the diversify of the learning process, presents the training material for students to learn in more visual and accessible way. Any scheme, illustration, animation, sound recording used in the organization of the educational process, become not just an attribute of the lesson, but make it more meaningful. With traditional methods of conducting the lesson, the teacher is the main carrier of information for students; helshe makes students concentrate and focus on the material. Not every student is able to work in this mode. The psychological features of the character and the type of comprehension of a student become the cause of failure. At the same time, modern requirements for the level of education do not allow to reduce the amount of information necessary for the student to master the topic of the lesson.

The use of ICT in the study of foreign languages contributes to:

- the development of various educational opportunities and abilities of students;

-the encouragement of the students to learn more about the history, culture and language of the foreign countries;

-the improvement of lesson effectiveness aimed to establish of interdisciplinary relationships; 
-the creation of conditions for self-education of students in areas of knowledge they are interested in;

-the use of visual aids at classes;

-the real experience of intercultural communication in a foreign language gaining;

-the ability to navigate in the modern foreign-language information environment.

Using and integrating the information resources of the Internet into the educational process, it is possible to solve a number of didactic tasks, in particular while studying a foreign language, more effectively, namely:

a) to develop reading and writing skills, using materials of a different difficulty level directly

b) to improve comprehension skills of a foreign language based on listening of the authentic audio texts taken from the Internet, as well as texts prepared by the teacher.

c) to enhance the skills of various types of oral speech on the different problems presented either by the teacher or some of the students using the network materials;

d) to promote the development of writing skills, implementing numerous kinds of tasks and exercises which can be done both individually and in groups, writing essays, compositions, wide range of correspondence in the process of joint activities with partners;

e) improving vocabulary and grammar skills while training with the help of programs, games, tests [7, p. 91].

Conclusions. Summarizing everything mentioned above, it should be concluded that the use of ICT in foreign language teaching improves the quality of the lesson's presentation and the effectiveness of students learning this material significantly. In practice, the implementation of modern technologies, and multimedia equipment enriches the content of the educational process, increases the motivation for foreign language learning and creates the close cooperation between the teacher and the student.

Evidently, the application of new information technology expands learning control capabilities process. Thus, the usage of computer programs in the system of current and intermediate control is particularly effective. On the one hand, specially designed test programs or databases, data containing test tasks provide the student with the possibility of self-control, on the other hand, they take on the routine part of the current or the final control. A computer testing system can be used as a separate program that does not allow modification of a universal program, depending on the completeness provided by the teacher [8, p. 260].

Moreover, there are numerous advantages, opportunities and priorities to implement information communication technologies into the process of education and introduce multimedia products in the foreign language teaching.

The use of information communication technologies in practical teaching allows us, first of all, not only to change and enrich the content of the pedagogical education, but also contribute to the educational and cognitive activity of students during the class.

The application of the multimedia tools in educational process allows both change the character of educational and cognitive activities of students and encourage the independent work of students with the help of various electronic learning tools. Besides that, the most effective application of multimedia in the foreign language teaching process in higher educational institutions contributes to mastering the primary students' knowledge, as well as developing skills and competences, necessary for vocational and professional training.

The potential benefits of information communication technologies, namely: the ability to build module testing system, adapt it to the needs of each user and a teacher, create specific training programs irrespective of time and place of study, as well as the ability to update the course quickly, are vivid. The application of the information communication technologies in the foreign language teaching process makes learning, teaching and studying more effective and individualized.

\section{Used literature:}

1. Могильна Н. Створення презентацій засобами Microsoft Power Point Інформатика, 2007. № 31-32. C. 28-36.

2. Пушкар О. Інформатика: Комп'ютерна техніка. Комп'ютерні технології: підручник для студентів вищих навчальних закладів. Київ : Академія, 2002. 704 с.

3. Телицина Т., Сидоренко А. Использование компьютерных программ на уроках английского языка. ИЯШ, 2002 . № 2.

4. Смолянинова О. Мультимедиа в образовании (теоретические основы и методика использования). Красноярск : КрГУ, 2003. $140 \mathrm{c}$.

5. Suppasetseree S. The Use of Moodle for Teaching and Learning English at Tertiary Level in Thailand Suranaree University of Technology. https://www.researchgate.net/publication.

6. Jaswinder S. How much your learners are engaged in your course? // https://www.lmspulse.com/2017

7. Расулова М. Использование информационно-коммуникационных технологий на уроках английского языка Теория и практика образования в современном мире: материалы II Междунар. науч. конф. СПб. : Реноме, 2012. С. 91-92.

8. Яцюк С. М. Вивчення наукових засад інформаційної підготовки фахівця Вісник Київського міжнародного університету. Київ : КиМУ, 2005. Вип. 7. С. 253-265.

\section{References:}

1. Mohylna, N. (2007). Stvorennia prezentatsii zasobamy Microsoft Power Point [Making presentations by means of Microsoft Power Point]. Kyiv : Informatyka [in Ukrainian].

2. Pushkar, O. (2002). Informatyka: Kompiuterna tekhnika [Computer Science: Computer Technology]. Kyiv : „Akademiia” [in Ukrainian].

3. Telitsina, T., \& Sidorenko, A. (2002). Ispolzovanie kompyuternyih programm na urokah angliyskogo yazyika [Application of computer programs at English lessons.]. Moscow : IYaSh [in Russian]. 
4. Smolyaninova, O. (2003). Multimedia v obrazovanii (teoreticheskie osnovyi i metodika ispolzovaniya) [Multimedia in education (theoretical background and methods of application)]. Krasnoyarsk : KrGU [in Russian].

5. Suppasetseree, S. The Use of Moodle for Teaching and Learning English at Tertiary Level in Thailand. / https://www.researchgate. net/publication.

6. Jaswinder, S. (2017). How much your learners are engaged in your course? / https://www.lmspulse.com/

7. Rasulova, M. (2012). Ispolzovanie informatsionno-kommunikatsionnyih tehnologiy na urokah angliyskogo yazyika [Application of information and communication technologies at English lessons]. Saint Petersburg: Renome [in Russian].

8. Yatsiuk, S. M. (2005). Vyvchennia naukovykh zasad informatsiinoi pidhotovky fakhivtsia [Studying the scientific basis of specialist training]. Kyiv : KyMU [in Ukrainian].

Бересток О. В., Щербина Ю. М. Застосування інформаційно-комунікаційних технологій як засобу формування знань у процесі викладання іноземної мови у закладах вищої освіти

Розглядаються можливості, щзо надаються технологіями інформаційних комунікачій (ІКТ) у процесі викладання іноземних мов. Визначені навчальні завдання на основі IКТ. Описано різні види діяльності, які сприяють ефективному оволодінню різними аспектами вивченої мови. Представлено переваги впровадження мультимедійних засобів у навчальний прочес вищої школи. Представлено кілька варіантів мультимедійних курсів, які використовуються для організації вивчення теоретичного матеріалу. Застосування багатофункиіональної системи моодlе на заняттях з іноземної мови для сприяння навчанню студентів. Підкреслюється важливість використання ІКТ на заняттях, спрямованих на урізноманітнення навчального процесу та подання навчального матеріалу у більш наочній та доступній для сприйняття формі. Зазначено інтеграиію інформачійних Інтернет ресурсів у навчальний проиес для ефективнішого вирішення ряду дидактичних завдань. Описано інформаційно-комунікаційні технологї як спосіб навчання, що використовується для підтримки, вдосконалення та оптимізачії доставки інформації. Розглянуто роль та перспективи вчителів, які впроваджують ІКТ на заняттях, виділяючи їх як вирімальних гравців у навчальному процесі. Проаналізовано методологічні та дидактичні припущення, щчо дозволяють виділити декілька напрямів дослідження. Визначено он-лайн діяльність як інструмент навчання, спрямований не лите на сприяння взаємодї та особистих контактах між людьми, а й на розвиток навичок навчання під час занять у формі додаткової діяльності. Досліджено ключовий засіб інновачій у формі факторів, щзо сприяють ефективному використанню ІКТ. Підкреслюється важливість інновацій як впливу ІКТ на підвищення якості освіти.

Ключові слова: інформаційно-комунікаційні технологї, мультимедійні курси, навчальний процес, навчальний матеріал, методична допомога, навички навчання, практичний результат, міжкультурна комунікація.

УДК 37.011.3-051:[37.18.8:005.336.3]

DOI https://doi.org/10.31392/NPU-nc.series5.2020.72-1.16

Біляковська О. О.

\section{МЕТОДОЛОГІЧНІ ПІДХОДИ ДО ВИВЧЕННЯ СИСТЕМИ ПРОФЕСІЙНОЇ ПІДГОТОВКИ МАЙБУТНІХ ВЧИТЕЛІВ У КОНТЕКСТІ ЗАБЕЗПЕЧЕННЯ ЇЇ ЯКОСТІ}

На основі аналізу наукових джерел схарактеризовано окремі методологічні підходи до вивчення проблеми професійної підготовки майбутніх учителів у контексті забезпечення ї̈ якості, зокрема, системний, діяльнісний (праксеологічний) та компетентнісний підходи. У ході дослідження забезпечення якості професійної підготовки майбутніх вчителів на основі системного підходу важливо виокремити головні елементи системи, попередньо розподіливщи їх на окремі блоки відповідно до визначення, функиіонування та процесу професійної підготовки. 3 позицій системного підходу, професійну підготовку розглядають як иілеспрямовану діяльність, яка заснована на певних принципах $i$ закономірностях системоутворювання, зв'язках між компонентами системи (метою, завданнями, змістом, формами і методами навчання у їх взаємодї тощо). Розглянуто головні принциии системного підходу, а саме: ицілісності, структурності, інтегративності, ієрархії, зовнішньої обумовленості та глобальної мети.

В умовах інтеграції вітчизняної системи освіти в європейський освітній простір перехід на компетентнісну основу підготовки майбутніх вчителів стає першочерговим завданням у забезпеченні ї̈ якості. Застосування компетентнісного підходу до досліджуваної проблеми уможливить перенести підготовку сучасного вчителя у компетентнісну площчину освітнього середовища, добір відповідних методів і форм навчання, спрямованих на підготовку компетентного вчителя-європейия, здатного до вирімення суспільних і професійно-педагогічних завдань, готового до продуктивної взаємодії, постійного розвитку, вдосконалення та зростання. Діяльнісний (праксеологічний) підхід до проблеми забезпечення якості професійної підготовки майбутніх вчителів спрямований на головне завдання - вивчення й упровадження необхідного знання для здійснення ефективної діяльності, а також ијіностей $і$ змісту, иілей, дій, процедур, результатів та відповідної корекиії.

Ключові слова: методологія досліджень, якість професійної підготовки, системний підхід, компетентнісний підхід, праксеологічний підхід.

На цьому етапі розвитку суспільства, якість є неодмінною характеристикою інноваційних процесів. Освіта, як важлива галузь та рушій прогресивних змін, у своїх модернізаційних пошуках в умовах 